\title{
ZLÍN: PUBLIC ART AND THE CITY
}

\author{
JANA ŠNÉDAROVÁ \\ Tomas Bata University in Zlín, the CZeCh Republic
}

\section{KEYWORDS}

Functionalist

Architecture

Participation

Public Art

Public Space

Site-specific

Urban Regeneration

\section{ABSTRACT}

In this article, the topic of public art in an urban environment of the postindustrial city is viewed in the context of one place - Zlín. Contemporary artworks integrated into the city spaces show the city as a site, in the context of its Modernist architecture and urbanism. They reflect both the past and the present-day changes in society and the way how we see and experience the world. Public art in Zlin has become part of the transformation and regeneration of public spaces fostering the enhancement of the quality of lives of local urban residents. It is evident from the research that Zlin can be perceived as a place with great potential for new art projects and for the public's participation and engagement. 


\section{Introduction}

$\mathrm{A}$ city is a living organism changing in time and space. "Cities, or better, the emerging global city, the matter today more than centralized nation-states..." (Potrč, 2004, p. 22). Irrespectively of how big they are, cities and their surroundings represent our future, and the quality of urban life is going to depend on the quality of the public space of cities. An urban environment exists as an entity shaped through complex processes of planning, design, and implementation. Its concept is derived from a human scale, gestures and movement, a concept that is easy to read by the public inhabiting and using these spaces As Garmory and Tennant emphasizes "spaces do not exist on their own, the success of a space depends on the context, the surrounding buildings or environment and the people using it" (2005, p. 1)

Works of art sited in urban public spaces have always been part of urban landscape animating and renewing its spirit, and easy to access by the audiences. The successful permanent public artwork, whatever its scale, promotes our responsiveness "to both topographical and social space as the open theatre of conscious being, and of both civic and personal relations" (Gooding, 1998, p. 19). Public art addresses the needs of urban residents - "by liberating their imaginations, contributing to the design of public spaces, and initiating social criticism" (Miles, 1997, p. 176). It has been interpreted in different ways, e.g. as art in the open spaces or as a sculpture in the open air. Art traditionally placed in the public realm for reasons of aesthetic enhancement, memorialization, or simply because introducing art into everyday life has been seen as an inherently good thing (Hall, 2003, 49). However, today's public art encompasses different concepts, and different forms of visual experience and its understanding often needs to be more progressive and put aside conventional notions and concepts. If the past decades have seen a steady increase in the volume of works intended for public spaces, there has been a scant critical debate on the subject until relatively recently" (Sellwood, 1996; Lovell, 1998; Hall, 2003; Knight, 2008). Nowadays, along with new architecture, redevelopment of cities and regeneration of city spaces, it has become the subject of deep inquiry. For the purposes of this essay public art can be understood as art located in spaces with open public access and reflecting the specific character of the given site. It promotes an aesthetic enhancement to an urban environment and improves the quality of people's lives. I assert that freely accessible public art is capable to encourage a deepened sense of identity and belongings to the given place among urban residents and promote participation and engagement and shared endeavor of people in creating a rewarding and pleasing urban environment.

In this article, public art is seen in the context of the "post-industrial landscape and urban regeneration" of one city - Zlín. This city needs to be perceived as an inherent part of European heritage, as a unique urban environment where functionalist architecture dominates the city, as a place that drew upon the best architectonic and urbanistic traditions of Modernism. Today's Zlín is at once "a historically significant architectural monument of European Modernism and a city with an active commercial life as well as a lively education system" (Klingan and Gust, 2009, p. 8). Klingan and Gust also point out that although there is no longer any large-scale industrial manufacturing in Zlín, it is not a shrinking run-down city. This postindustrial urban area located in the south-east of the Czech Republic is converting rapidly into a modern vibrant university city of culture and education, a city of contemporary art and design. I argue that it is at once a young and an old city that has a big potential for further redevelopment and regeneration of public spaces. Its story can be told from many different perspectives - the one of architecture and urbanism, design and public art, as well as in the context of its modern history.

Public art, public space, and site are seen in the context of the city of Zlín and are the main issues explored here. How can people identify themselves with the city of Zlín through public art? What role does public art play in the lives of urban residents? In what way can public art change and transform the quality of urban space and, consequently, the quality of people's lives? These research questions have been arising debates among artists, designers, architects, urban planners and - last but not least - among the public nowadays, more than ever before, 
and have become the heart of this research. The issues of Zlín functionalist architecture and urbanism have been examined in detail in many literary sources including monographs, journals, and catalogs from international conferences (Novák 1993; Horňáková, 2009; Klingan and Gust 2009; Bittner, Hackenbroich and Schneider 2012; Pokluda 2015), but the published research on public art in Zlín has not been done to date. The methodological approach intended for this piece of empirical, qualitative research will include surveys, interviews, focus groups, but the main research strategy will be the case study. This method enables an in-depth and detailed examination of one issue (Stake, 1995, p. 2). Nevertheless, it is not the intention of this essay to be a manual of public art in the city of Zlín. It is rather an attempt to show (on a few selected pieces of public art) the variety and diversity of forms, concepts, and approaches that are concerned with, and reflect the spirit of the urban environment of Zlín. At the same time, these works of art ranging from temporary installation to permanent figurative works of art are becoming narratives open to diverse readings and understanding of the text of the artworks by the public.

Firstly, this essay will outline some premises that stimulated the transformation of the urban environment of an originally provincial town, and that led to the birth of a modern urban entity. Working within the critical framework that has been outlined here the role of public art in the regeneration of public spaces and, consequently, the enhancement of the quality of lives of local urban residents will be examined on a few examples of contemporary public art in the Zlín environment. Finally, an emphasis will be laid on the issues of the public's response, engagement, and interaction.

\section{Zlín - Origins of the Functionalist City}

To contextualize the site and artworks discussed in this piece of research it would be useful to look back to the origins of Zlín and its modern history and chart briefly some of the most significant events that led to the birth of the place as a modern entity. The beginnings of its modern history covering the first decades of the 20th century are closely associated with the development of the Bat'a shoemaking company.
When Tomáš Bat'a and his siblings Antonin and Anna established a shoemaking enterprise on Zlín's town square, Zlín at the time had a population of barely 2,500 (Šlapeta, 2009, p. 54). The company grew rapidly having expanded in a few decades of the 20th century into a global enterprise. The small-town structure located in the south-east of pre-war Czechoslovakia transformed into a modern industrial urban area designed and created according to a coherent plan as a model city for functionalist architecture and the headquarters of the company. As Wilhelm explains, key features of this model architecture were industrial plants built to fit Fordist production demands surrounded by standardized housing units in green spaces, cultural and educational buildings, sports facilities and health centers. These features were functionally distributed in a number of districts and areas all over the world. (2009, pp. 232-233)

\section{1. "A utopia of modernity that became real..."}

In a phrase that was to gain legendary status, Le Corbusier had called Zlín a "resplendent phenomenon" (as cited in Volkers, 2009, p. 6). Le Corbusier was invited to Czechoslovakia in 1935 by the chief Zlín architect František Lydie Gahura to take part in a competition. Le Corbusier had designed a strip-like structure divided into mono-functional zones, which "were strung like pearls on a necklace in the landscape" (Wilhelm, 2009, p. 233). Wilhelm also states that he later employed the planning approach developed for Zlín in the objectives of his Cité Linéaire Industrielle from 1945 (pp. 223-235). As Bittner (2009) points out;

Here in the 1920s, far from the centers of the Czech avant-garde and the focus on the New Objectivity, the entrepreneur Tomáš Bat'a had the architect František Lydie Gahura build a new town, one that was coordinated to accord fully with the needs and rhythms of the factory. The structural principles of industrial production standardization and rationalization - were transplanted to the organization and configuration of urban space. Made up of pale reinforced concrete skeletons, their texture visible, red-brick infill and band-shaped glass fronts, the basic module of $6.15 \times 6.15 \mathrm{~m}$ left its distinctive mark not only on company buildings, but also on colleges, schools, hospitals, 
community facilities, and the company department store (p. 252).

Zlín itself is the result of the frequently criticized mechanism producing a city, the result of rational organization and the complete redistribution of its parts and functions. At the same time, it is in Zlín designed by the architect František Lydie Gahura in the 1920s for the shoe manufacturer Tomáš Bat'a that the idea of the city as debated in the utopian and urbanist discourse of its age finds its first large-scale realization (Völkers, 2009, p. 6). The planned city was an innovative manufacturing location, its development geared fully to functional ends, a half-garden and a half-industrial city. Here industrial and living areas together with public space for relaxation and entertainment became integral parts to the city.

Figure 1. Former factory premises - Building No. 21

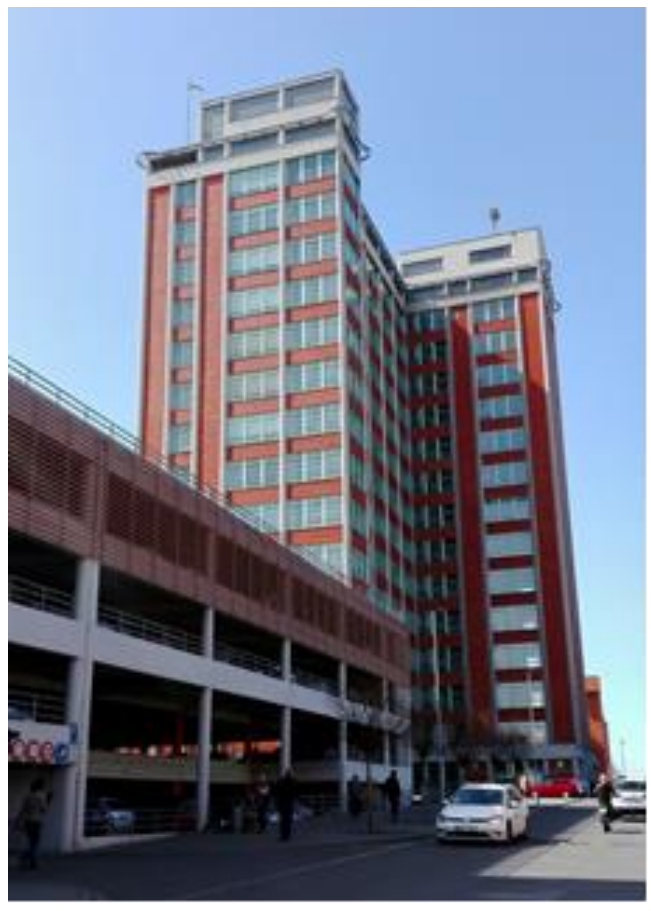

Source: Own photo, 2018

\section{2. "An Island in a Sea of Industry"}

As mentioned above, "Zlín itself is an exceptional place, one where past and present overlap, where the architectural and intellectual heritage of this city is still tangible here" (Klingan and Gust, 2009, p. 8). Unlike traditional cultural centers and historical cities, there was no artistic tradition and continuity in the utilitarian environment of the city of Zlín with an emphasis on work performance and economic results and until the mid-30's the sphere of fine arts had solely been represented by functionalist architecture. Tomáš Bat'a and his half-brother Jan Antonín - the shoemaking factory founders and owners were not only ambitious entrepreneurs and managers of industry. These two self-made men knew how important it is to surround themselves with "the best co-workers and also expert architects and structural engineers" (Nová, 2009, p. 41). They were pragmatic and very well-aware of tight connections between production and design and the importance of education. Education, employment, housing, and social benefits attracted hundreds of young people to Bata's factories and schools. "Here a lively city milieu had developed out of the coexistence of working, recreational and education zones" (Wilhelm, 2009, p. 233). Educational institutions, advertising film studios, a regional gallery of fine arts and other cultural and recreational facilities for the public was established in the 1930s. In the inter-war period, Zlin had become, albeit for a short time, one of the most important centers of culture with its art festivals - Zlin Salons, advertising film studios, educational and cultural institutions, a regional gallery of fine arts and other cultural and recreational facilities. Zlín had no longer only been an industrial city with large factory premises but evolved into a viable dynamic city of art and culture and an attractive venue for artists to meet and exhibit their works of art at Zlín Salons (Ševeček, 1996, pp. 6-13). Ševeček also concludes that these annual displays of contemporary art became an event of international significance having no parallel both in the context of the contemporary Czechoslovak and central-European art at that time. The only school specializing in industrial design in former Czechoslovakia based on the Bauhaus movement was set up in 1939 by Jan $A$. Bata. It was initially meant to serve the company's own purposes, but soon, it attracted leading personalities of the Czech avant-garde artists, architects, and designers who were invited to teach and educate a new generation of artists. (Scholz, 2009; Kolesár, 2015). Zlín became not only an industrial city with large factory premises but also a vital city of art and culture.

World War II and the following years of the totalitarian communistic regime affected the whole society. The political situation in central and Eastern Europe in the post-war period brought about censorship, persecution of 
political opponents, and political trials and strongly affected the sphere of art and culture conforming to communist ideology. The totalitarian communistic regime meant, among other things, the end of intellectual and artistic liberties. The closing XI Zlín Salon was held in 1948. (Ševeček, 1996, pp. 6-13)

"If Zlín is ,Europe's city from yesterday, then a question arises as to how we can think about the city of tomorrow." (Volkers, 2009, p. 7). The 1990s saw radical changes in the society and the period after the Velvet Revolution was accompanied by difficult economic transformation of the country (Šlapeta, 2009, p. 67), but there has been a growing effort to restore, redevelop and the city and charge it with the renewed vitality since the beginning of the new millennium. I argue that today's Zlín can draw not only on its architectonic, urbanistic and cultural heritage, but, first and foremost, it can be perceived as a place with a great potential in promoting cultural diversity and variety, contributing to the local distinctiveness and emancipation of the city, bringing into life new art and cultural projects supporting participation and engagement of people that, consequently, can help local residents to identify themselves with the Zlín urban environment.

\section{Public art, public space, and site}

Buildings No. 14 and 15 are two structures out of the complex of more than one hundred buildings found in the premises of the former factory grounds. They used to serve the manufacturing processes in the past and were revitalized and opened to the public only recently, in 2014. These "twin" buildings have been transformed in the regional educational and cultural center - the Ba'ta Institute 14/15 now housing the Regional Gallery of Fine Arts, the regional library and museum. The Ba'ta Institute has become a venue for culture projects inviting people of all generations, both from the sphere of art and non-artists, to present their art projects and participate and engage themselves in the events ranging from art exhibitions, temporary installations, video mapping, film projections, lectures, fashion shows - to mention just some of them. Many times, it has become a venue for the triennial symposia and exhibition Space Zlín devoted to art in public space (Ševeček, 2011). Other triennial exhibitions - renewed Zlín Salons and Zlín Salons of Youths or Zlín Design Week provide new opportunities for both artists and the public to be close to art, to encounter and experience art in the city streets. Within these exhibitions, some works of art displayed there became both temporary interventions into the city spaces and permanent artworks that we can find in the city streets nowadays. I argue that Zlín is a perfect example of an urban environment where one can explore the issues of public art, space, and the site as it represents unique urban settings where Modernism became the principal language we use to communicate about the city.

As Henry Moore said in 1995: “...the settings make a difference to the mood with which one approaches a sculpture, and a good setting is one in which the right conditions are present for a thorough appreciation of its forms." (as cited in Gooding, 1998, p. 17). The identification of space as a site is the main point of reference for the artists working in open spaces and as Lovell (1998) states "site-specificity, a term fashionable in 1987, has been superseded by the dialectics of space and site, social geography and the gendering of place" (p. 10). Adams (1997) defines the site as a physical, social and cultural setting for the artwork that embodies messages and meanings apparent to local people (p. 79). Adams also emphasizes its appropriateness, not only in terms of public access but also how people perceive and use the site, the associations and meanings linked with it (p. 76). I assert that public art and site are closely interdependent; the context of the site affects the work of art, its meaning, and its form and thus becoming integral parts to each other. Artists working in Zlín often use alternative materials, forms and means of interpretation to reflect the city's genius loci, its history and future, and the present-day reality. This new public art offers different forms of visual experience and its understanding needs to be more progressive requiring to put aside conventional notions and concepts, to look and think about art anew, in a fresh way. The role of artists is to communicate and interact with a broad and diversified audience to open new sites of debates about what public art is, what it can say to a random passer-by. Public art has also become closely associated with the regeneration of city spaces. Artists characteristically lead the way in urban 
regeneration. They are also the first to recognize potential and to act in the transformation of space (Lovell, 1998, p. 11). As already mentioned, public art promotes an aesthetic enhancement of urban environments and helps to the improvement of the quality of people's lives. According to Adams (1997), public art can contribute to local distinctiveness and create a sense of place or regional identity (p. 7), and creates the feeling of belongings to the city, and its actuality.

As seen from the art projects that have been realized to date and works of art sited in the public spaces of Zlín some of these works of art have marvellously been integrated into architectural space offering a radically new view on the city space and as Acconci (2004) points out "...the site provides not only the place for the project but also the matter of the project - the project is built with the site and by means of the site...". (p. 31)

\subsection{Rational geometry}

Petr Stanický is an internationally renowned Czech artist based in Zlín who has been working here since 2008 (Horňáková, 2012, pp. 28-29) and since then, he has been deeply concerned with the aesthetics of Zlín urban environment and its industrial architecture. "In Zlín architecture, he has found a piece of what he encountered much more frequently during his long stay in the United States" (Mílek, 2013, p. 32 ). It is the "specificity" of the site and its genius loci that inspire him and the reason why he repeatedly returns to the theme which already accompanied him at the beginning of the previous decade. Concerned with the integration of art into the architectural fabric Stanický himself aptly calls his works of art "architectures". The purity of forms and materials (construction steel and glass) of his site-specific objects connect with the purity of expression. His simple geometrical structures resembling the purist abstraction and minimalist layout of the city streets are sited in the spaces of the former factory premises that are freely accessible to the public. During the triennial exhibition Space Zlín 2013, Stanický created a site-specific object called "\#14". This permanent work of art was incorporated into the entrance of building No. 14 even when its reconstruction was still in progress and became an integral part to it. Nowadays, this building houses the regional gallery and neither a random passer-by nor a gallery visitor can miss it. It attracts our attention, obstructs the way, and makes you involve your senses and mind. As Mílek (2013) points out the use of materials - the construction steel grids - remind us of the "rational geometry" of the city inspired by the raster of windows, walls, layout, and geometry of buildings. The horizontal and vertical lines create networks and Stanický makes layers of these metal grids that evoke the rational composition of the city. A big glass board, like a museum showcase, reflects the images of the past and, at the same time, it mirrors the reality of the city streets, the architecture of buildings standing opposite, the individual's reality. It makes you stop and look what's behind the glass, to uncover the core of the structure. The viewer is drawn in, engaged and involved and, simultaneously, confronted with the reality of daily life, and the site itself.

\section{Figures 2 "Architectures” by Petr Stanický}

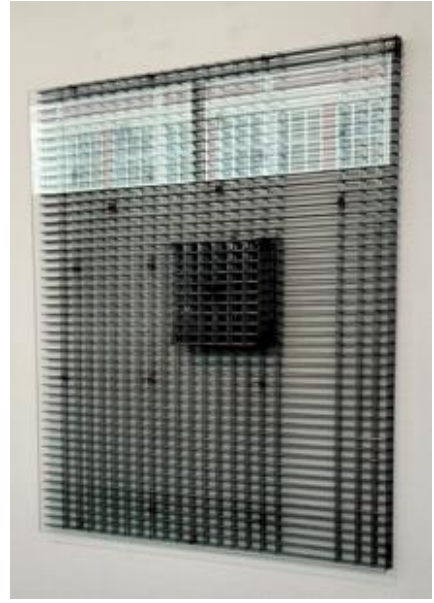

Source: Own photos, 2019

Figures 3 "Architectures" by Petr Stanický

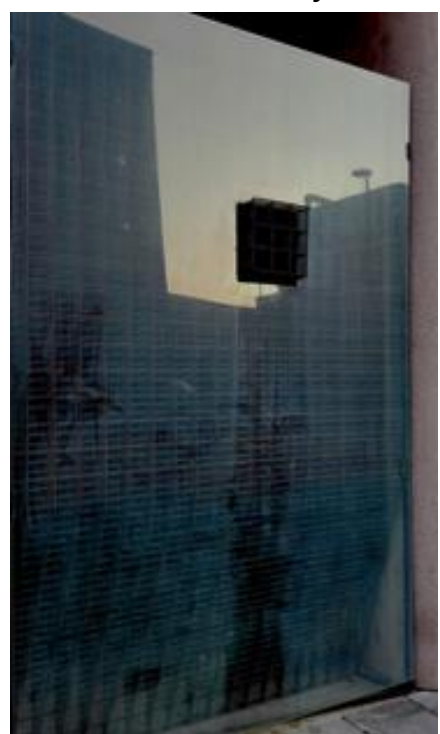

Source: Own photos, 2019 
Figures 4 “Architectures” by Petr Stanický

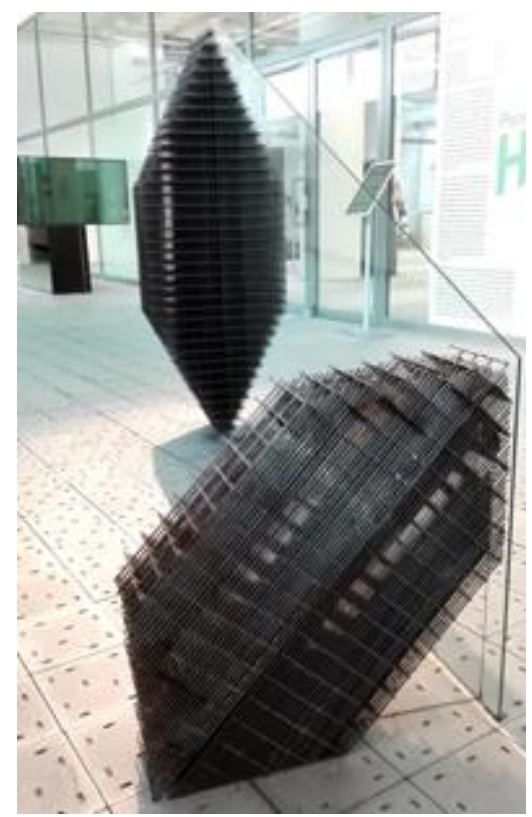

Source: Own photos, 2019

Traditional public art was aimed to celebrate and commemorate important events of historic significance such as a military victory or to depict a national hero, to educate, enlighten or entertain and to provide an aesthetic experience (Knight, 2008, p. 23), According to this concept, public art in public spaces is intended mainly for representation, it should be generally comprehensible and express socially acceptable ideas. Conventional tributes inappropriate places are expressions of communal pride, but they rarely enter into a creative engagement with the spirit of the artist's work and with the site itself (Gooding, 1998, p. 14). Great Fibonacci by Rudolf Valenta represents a unique work of art where the concept of rational geometry was applied in its ultimate form. Sited on a lawn area just in the middle of the largest Zlín square (Labour square), in the closer proximity of the newly revitalized walk-through, a twenty-two-meter long pointed line made of bright stainless steel intersects the space and has become a central structure of this large area. Unlike traditional historic city centers where the principal dominant of the city square is presented by a water fountain, a statue on a plinth, a plague column or a memorial to a national hero, here a sequence of triangles dominates the main square. Great Fibonacci - a work of art created by one of the leading figures of the Czech and international constructivism (Vrbková, 2011) is the finest expression of an abstract idea of the mathematical representation of space. It was inspired by the famous Italian Renaissance mathematician Leonardo Fibonacci and his infinite sequence of numbers when each number is the sum of the two preceding ones. There is also a strong connection between this arithmetical sequence and composition of an artwork expressed in the golden ratio. Nevertheless, this piece of art cannot be regarded as a truly site-specific public art created for a singular space. It had been designed and firstly sited in Gundelfingen, Germany in 1984 (Vrbková, 2011) and then later displayed during the triennial exhibition Space Zlín 1994. It is only recently that it has been incorporated into the new public spaces adjacent to the newly revitalized Zlín walkthrough in the city center. It complies with the space drawing a big deal of the public's attention and both excites people and arouses debates. The sophisticated composition of Valenta's Fibonacci amazingly reflects geometrical principles and order of Zlín architecture. Individual parts of the objects are reduced to basic geometric shapes - triangles, straight lines - and their mutual relationship, space intersections and location create a distinct architectural concept.

Both works of art can be credited as examples of good practice of siting public art in the city spaces. It is virtually impossible not to notice these works of art in the public space of Zlín. They may be understood in different ways and they are open to varied interpretations and ways of reading and comprehension. Sometimes, they obstruct the way, sometimes they excite and sometimes incite debates. In spite of the different concepts and formal interpretation, they have the potential to engage urban residents and attract the attention of those who encounter them in the city's public spaces. 
Figure 5. Great Fibonacci by Rudolf Valenta

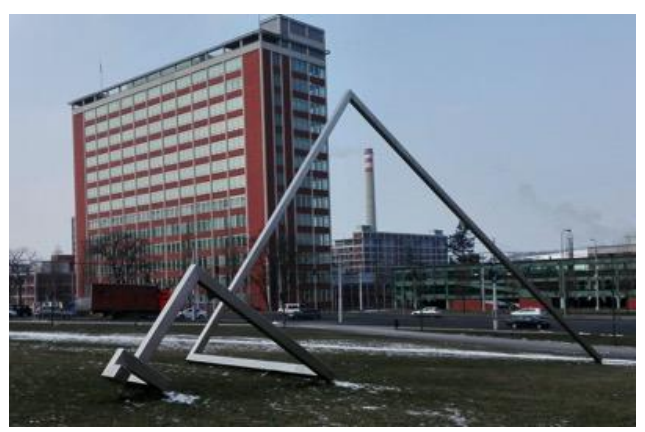

Source: Own Photos, 2019

Selwood emphasizes public art's social, and economic impacts: "it is credited with being a cultural investment vital to the economic recovery of many cities, contributing to local distinctiveness and cultural tourism, increasing the use of open spaces, humanizing the built environment, encouraging residents to take greater pride in their locality and creating employment and confidence among various communities" (1996, p. xv). But public art can serve many purposes. The 1990s had to face radical changes in the society - economic transformation, discontinuation of the manufacturing processes and closure of the factory premises. In an effort to provide decaying urban spaces with an impression of change, and regeneration some public works of art were often incorporated in the brownfield areas insensitively with no respect to the context of the artwork and of the site. Hall (2003) argues that most of the public art produced within the projects of urban regeneration in major cities is produced in the interests of local authorities and commercial developers and thus, as so-called institutional art, it represents an elite vision of a city. Knight (2009) points out that such public art is used "to hide economic and social reality" (p. 54). Miles (1997) asks "what does publi c art placed outside a bank head office, incorporate spaces say, apart from that the bank and property developer are successful enough to be patrons of art (and as of architecture)" (p. 87). Hall also argues that "the contradiction between the image - how public spaces and public artworks are represented by the minority and the appearance - the way the public spaces are seen and experienced by the majority is the main issue of public art". (p. 52)

The most striking example of this practice in Zlín became the relocation of one of the most valuable works of public art - The birth of a star by a renowned designer and sculptor Zdeněk Kovář (Jakubíček and Mílek, 2015, pp. 189192). The concept of rational geometry of this futuristic sculpture made of bright stainless steel can be perceived and interpreted in different ways, it is capable to offer different ways of reading to local people; it has a strong intellectual message. The text of the work can be read as an expression of the human's endeavor, ambitions and heading for the future. Nevertheless, this intellectual message is "spoilt" when the meaning and the site are not linked in artwork and when "the right conditions are not present for a thorough appreciation of its forms" (p. 17) to paraphrase Henry Moore's quotation. Removing the Star from its original position in the Zlín housing area and its relocation in the former factory premises owned by an influential financial group irrespectively both to the specificity of the site and to the text and meaning of the work was an insensitive intervention into the autonomy of the artwork.

Figure 6. The Birth of a Star

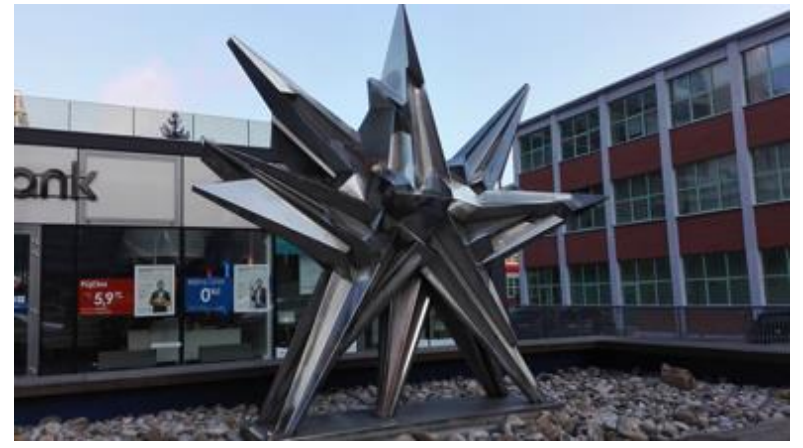

Source: Own photo, 2019

\subsection{Narrative Space}

Urban places have their own history and atmosphere - their genius loci. Public spaces their design, culture, and atmosphere - are shaped through time, by political, economic, social and environmental changes and through activity, energy, and endeavor of people who live there. According to Miles "public space is 'more than the space leftover in plans', it also implies a recognition that cities have a social reality as well as a physical form because it is where socialization takes place" (1997, p. 193). Places are capable to reflect the multivalent realities of cities, their past, and present and bring into life creative dialogues and debates 
among those who are using them. In his essay, Gooding (1998) uses what Walter Grasskamp has called "the city as a narrative space". This new kind of narrative requires to view public space and public art anew and to open new sites of reading and understanding the text of public art by the audiences.

The need to create permanent memorials to celebrate personalities, national heroes and important events in history goes back to classical times. The main function of public art in the city spaces has always been aimed to celebrate and commemorate important events of historic significance such as a military victory or to depict a national hero, to educate, enlighten or entertain and to provide an aesthetic experience (Knight 2008, 23). According to this concept, public art in public spaces is intended mainly for representation, it should be generally comprehensible and express socially acceptable ideas. Gooding (1998) also points out that conventional tributes in appropriate spaces are expressions of national pride, but they rarely enter into a creative engagement with the spirit of the artist's work. (p.13)

Tomáš and Jan Antonín Bat'a's memorial by another renowned Czech sculptor - Radim Hanke (Mílek, 2013, p. 39) - forms a counterpoint to the purely abstract and constructivist non-figurative concept of Valenta's Great Fibonacci. Statues of both brothers are situated in the University Park opposite the constructivist structure. They symbolically face the Zlín Administration building (often called building No 21), the former company's headquarters and an iconic building of the Czech Modernism. The statues are standing side by side on a plinth - its format replicates the basic module used for Zlín architecture. The memorial represents a traditional, conventional concept of interpretation which is easier to read and understand by the people who are not interested in art and hardly ever visit galleries and museums. This monument was commissioned by the local authorities and intended as a tribute to the two men - the cofounders and owners of the Zlín shoe-making empire. It authentically reflects the character and relationship of both brothers as well as their families. Mílek (2013) emphasizes the significantly different body language, the position of the two brothers - the closest allies.
Later, after Tomáš Bat'a's death, antagonisms caused by the property disputes interrupted and cut the close family ties and both branches of the Bat'a family became probably the most bitter enemies. They did not even agree with the intent to position both figures side-by-side on one plinth.

Both form and text or meaning of art can arouse discussions on the presence of public art in the city spaces. These debates are the more important that the voice of the public can be heard and the public can be involved. The text and meaning of the monument became for some people, if not controversial, at least disputable polarizing the public. A young Slovak artist, Martin Kochan „reused” this monument for a temporary installation during the triennial exhibition „Space Zlín 2013” (Mílek 2013, 3847). He interconnected both statues with an oversized plastic shoelace bearing the name Anna - a co-founder and, in the early years, a part-owner of the company and sister of both brothers. The shoelace as a symbol of the shoemaking industry and mainly the name of their sister on it ties up both brothers and thus also antagonized branches of the Bat'a family. Wit and gentle sense of humour can soften antagonisms and critical debates. Public art as an intervention in the public realms and as a form of continuing social criticism needs to be challenging or even provocative, or better funny or witty to capture attention and imagination of the widest possible audiences. Public art needs to become topics for discussions and debates among local city dwellers, involve engagement and interaction with the art world and arouse critical reactions and even controversies, works of art in the city streets can teach us to think about art anew, they are capable to convey strong intellectual and emotional messages speaking to people's hearts and intellects directly and even those who do not visit galleries - random passers-by - can be inspired and surprised. 
Figure 7. Tomáš and Jan Antonín Bat’a's Memorial by Radim Hanke

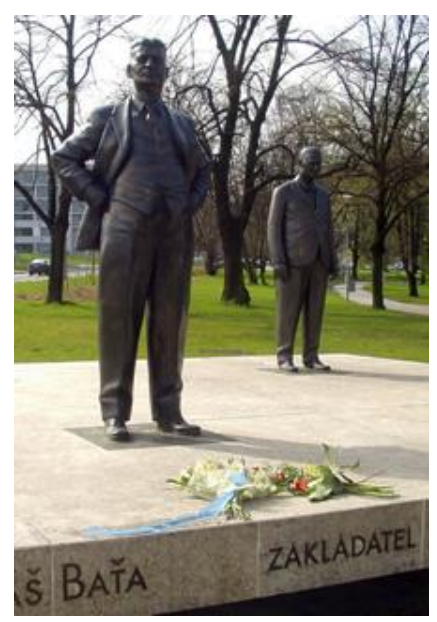

Source: Own photo, 2019

\section{Summary}

Zlín is a unique urban environment and the heritage of the functionalist architecture is still tangible here. Public space - its design, culture, and atmosphere - changes through time by the activity and energy of people who live there. Every space has its own narrative that brings into life the dialogue that reflects the multivalent realities of the city - their past and present. It is clear from the research that public art is a cultural investment vital not only to the economic recovery of the city, but it also increases the use of open spaces, contributes to local distinctiveness, cultural diversity, emancipation, and identification with the local environment. Through art, people can better understand and reflect the history of the city and its genius loci. Works of art chosen for this piece of research show the diversity and variety of public art in one city - Zlín. In spite of the different concepts and formal interpretation public art invites urban residents to participate and engage with the art and arouses debates among people who encounter it in the city streets. Public art incorporated in brownfield areas cannot be merely used to hide economic and social reality. It has a big potential to enhance the urban environment, and thus improve the quality of people's lives. Zlín must be seen in its complexity, both in the context of the functionalist architecture and as a unique place transforming into a modern city that has both positive aspects and limits. Zlín is not a post-industrial wasteland. It is rather a young lively university city of culture, art, and design. It is evident that future development will require more investments in the city spaces where there is still a great potential for new art projects and for the public to be involved and engaged with the art. 


\section{References}

Acconci, V. (2004). Leaving home - Notes on insertions into the public. In F. Matzner (Ed.), Public art: A reader (pp. 28-33). Ostfildern-Ruit, Germany: Hatje Cantz Verlag.

Adams, E. (1997). Public art: People, projects, process. London: London Arts Board.

Bittner, R. (2009). Elevator effect urbanity. In K. Klingan, and K. Gust (Eds.), A utopia of Modernity: Zlín: Revisiting Batas functional city (pp. 248-59). Berlin: Jovis.

Bittner, R., Hackenbroich, W., \& Schneider, P. (2012). Architektur aus der schuhbox: Bat'as internationale fabrikstädte [Architecture out of the shoebox: Batª's international factory towns]. Leipzig, Germany: Spector Books.

Garmory, N., \& Tennant, R. (2005). Spaced out. A guide to award winning contemporary spaces in the UK. Oxford: Routldge.

Gooding, M. (1998). Public:art:space: A decade of public art commissions agency, 19871997. London, Merrell Holberton.

Hall, T. (2003). Opening up public art's spaces: Art, regeneration and audience. Advances in art, urban futures. Issue 3: 49-57.

Horňáková, L. (2009). Afterword: A utopia made real. In K. Klingan, \& K. Gust (Eds.), A utopia of Modernity: Zlín: Revisiting Batas functional city (pp. 274-76). Berlin: Jovis.

Jakubíček, V., \& Mílek, V. (Eds.). (2015). Ostrov umění v moři průmyslu: Zlínská škola umění (1939-1949) [An island of art in a sea of industry: School of arts in Zlín (1939-1949)], (1st ed.) Zlín: Krajska galerie vytvarneho umění ve Zlíně [Zlín: Regional gallery of fine arts in Zlín].

Klingan, K., \& Gust, K. (Eds.). (2009). A utopia of Modernity: Zlín: Revisiting Batas functional city (1st ed.). Berlin: Jovis.

Kolesár, Z. (2015). Dve bauhausovské inšpirácie-Škola umeleckých remesiel a Škola umění ve Zlíne [Two Bauhaus inspirations-School of arts and crafts in Bratislava and School of arts in Zlín]. In V. Jakubíček, and V. Mílek (Eds.), Ostrov umění v moři průmyslu: Zlínská škola umění (1939-1949) [An island of rrt in a sea of industry: School of arts in Zlín (1939-1949)], (pp.79-87). Zlín: Krajska galerie vytvarneho umění ve Zlíně [Zlín: Regional gallery of fine arts in Zlín].

Krause Knight, Ch. (2008). Public art: Theory, practice and populism. Oxford: Blackwell Publishing.

Lovell, V. (1998). Introduction. In M. Gooding (Ed.), Public:art:space: A decade of public art commissions agency,1987 - 1998 (pp. 10-11). London: Merrell Holberton.

Mílek, V., \& Fišr, M. (2013). Prostor Zlín 2013 [Space Zlín 2013]. Zlín: Krajska galerie vytvarneho umění ve Zlíně [Zlín: Regional gallery of fine arts in Zlín].

Miles, M. (1997). Art, space and the city: Public art in urban futures. London: Routledge.

Nová, D. (2009). They were ahead of their time. In K. Klingan, \& K. Gust (Eds.), A utopia of Modernity: Zlín: Revisiting Batas functional city (pp. 41-52). Berlin: Jovis.

Novak, P. (1993). Zlínská architektura: 1900-1950 [Zlín architecture: 1900-1950]. Zlín: Agentura Cas.

Pokluda, Z. (2015). Bat'ưv Zlín: Budování průmyslového a zahradního města (1906-1943) [Batas Zlín: Building an industrial and garden city (1906-1943)]. Zlín: Nadace Tomaše Bati [Tomaš Bat’a Foundation].

Potrč, M. (2004). Public space in contemporary city. In F. Matzner (Ed.), Public art: A reader (pp. 18-27). OstfildernRuit, Germany: Hatje Cantz Verlag.

Scholz, A. (2009). Industrial design from the spirit of sculpture. In K. Klingan, \& K. Gust (Eds.), A Utopia of Modernity: Zlín: Revisiting Batas Functional City (pp. 196-201). Berlin: Jovis.

Selwood, S. (1996). The benefits of public art: The polemics of permanent art in public places. London: Policy Studies Institute.

Ševeček, L. (1996). Z historie Zlínských Salonů [From the history of the Zlín Salons]. In L. Ševeček (Ed.), 1. Nový Zlínský Salon [First New Zlín Salon], (pp. 6-13). Zlín: Statní galerie [Zlín: The State gallery].

Šlapeta, V. (2009). The Bat'a legacy: The realization of a utopia. In K. Klingan, and K. Gust (Eds.), A utopia of Modernity: Zlín: Revisiting Batas functional city (pp. 53-67). Berlin: Jovis.

Stake, R. E. (1995). The art of case study research. London: SAGE.

Völkers, H. (2009). Foreword. In K. Klingan, \& K. Gust (Eds.), A utopia of Modernity: Zlín: Revisiting Batas functional city (pp. 6-7). Berlin: Jovis.

Vrbková, J. (2011). Rudolf Valenta \& János Fajó, 6. 9. - 28. 10. 2012. Retrieved from http://www.galeriezavodny.com/en/index.php?p=52

Wilhelm, K. (2009). The Earth, a good domicile': Ambivalencies of the modern city. In K. Klingan, \& K. Gust (Eds.), A utopia of Modernity: Zlín: Revisiting Batas functional city (pp. 225-37). Berlin: Jovis. 